\section{Change in New Guinea}

The Chimbu: A Study in the New Guinea Highlands. By Paula Brown. Pp. ix +151 . (International Library of Anthropology.) (Routledge and Kegan Paul: London, July 1973.) £3.25.

DR BRown has, during a period of 15 years, observed the effects of social change in the population of the New Guinea Highlands. This group of people was first discovered by an Australian prospecting expedition in 1933 and many observations were made by administration officials, missionaries and an occasional anthropologist. These records were available to Dr Brown and with her own observations from 1958 onwards, she has been able to make a careful study of the effects of social changes. There is probably no other country in the world where it has been possible to observe profound changes which have occurred over a relatively short time. New Guinea has consequently become a haven for anthropologists but $\mathrm{Dr}$ Brown has made one of the most complete studies.

The Chimbu are usually regarded as among the most intelligent and energetic people in New Guinea and as Dr Brown describes, after an initial turbulent period, they seem to be adopting European culture with apparent enthusiasm. The introduction of medical services in recent years has reduced the infant mortality and this, in turn, has caused overpopulation. A few years ago the severe disease kwashiokor, due to under-nutrition, was prevalent amongst Chimbu infants but this no longer occurs. Local government councils, the introduction of the internal combustion engine for transport and for agricultural purposes, the provision of schools, trading stores, cash crops, missions, European dress, roads, the development of law enforcement and political debating are all part of the new European culture. It is a fascinating story related accurately and entertainingly by $\mathrm{Dr}$ Brown.

The 19 chapters of the book are clearly divisible into three parts. The first describes the historic features of the life of the Chimbu people, the second is concerned with the dynamics of tribal life and the third describes many of the effects of change.

A biologist perhaps might be pardoned if he regrets that the biological changes, especially those affecting the growth and development and general health standards of infants and children in the area, were not studied at the same time as the social changes. It is known that such changes have occurred and their correlation with the cultural and social study of Dr Brown would have been interesting. An adjacent area was the scene of the recent study during the International Biological Programme. Regrettably the latter did not include a study of the effects of social change such as that undertaken by $\mathrm{Dr}$ Brown in Chimbu. The problems of communication between different groups of research workers are often as great in New Guinea as in the more advanced countries, and opportunities are lost.

\section{R. J. WALSH}

\section{Soviet geology}

Geology of the U.S.S.R. By D. V. Nalivkin. Translated from the Russian by N. Rast. Edited by N. Rast and T. S. Westoll. Pp. xviii +855 . (Oliver and Boyd (Longman): Edinburgh, November 1973.) ' $£ 25$.

Apart from a very slim volume, published in translation in 1960, this is the first and only comprehensive work on the geology of the Soviet Union in English and so, whatever its quality, 855 pages of close type must be taken very seriously. But in relation to the immense geoscientific output from the Soviet Union, with so many multivolume series on systematic aspects of Soviet geology, this work also is possibly unique in covering so large a field within a single volume.

It suffers a little from age. The interval between 1962 when published in the Soviet Union and late 1972 leaves a time of very great progress in Soviet geology unrecorded. But the value of the work to the English reader is to set the whole range of Soviet geology in perspective in a single framework, which in broad outline at least is hardly affected by recent work. So this volume serves as an introduction for western geologists as well as Soviet students to that vast territory.

The scheme of the book is distinctive. and as in so many general works in Russian science there is a rather explicit ohilosoohy. reflecting scientific as well as political fashion (more than ten years old). In this case the philosoohy is made to work throughout the volume. In short it is that geological history can best be understood in terms of geosynclinal development taken in a somewhat comprehensive, genetic and extensive way so as to include many aspects of tectonics including orogeny.

In consequence the book is classified thus: part 1, introduction; part 2, Precambrian geosynclines (Russian platform; Siberian platform; Western Siberian lowlands); part 3, Palaeozoic geosynclines (Uralian geosynclines; Western Artic geosynclines; Argara geosynclines; Middle Asiatic geosynclines); and part 4, Meso-Cainozoic geosynclines (Mediterranian geosynclines; Pacific Ocean geosynclines).
There is indeed considerable attention paid to these controlling concepts both in the introduction with its historical review of Russian geology and a treatment of such principles, as well as in the translator's introduction. This treatment is indeed quite effective because geosynclines are strata, and the book adopts a thorough and explicit stratigraphical approach to tectonics, magmatism, and useful minerals in each chapter. This coherence is its strength in that a great amount of detail is well organised; it is also well referenced and well indexed.

Because such a unified approach is, with increasing knowledge and specialisation in the Soviet Union, likely to become less and less possible, this work will probably stand without competition as one of the classic regional descriptions, in the line of Heim's Geologie der Schweiz, David's Geology of Australia, and the recent multiauthor Geological Survey work on Canada. Indeed national pride harnessed in this way is most welcome.

Professor Rast is an experienced translator and the work reads well in English. The many photographic illustrations give a sample of varied field conditions in that vast territory directed towards the student population about to explore it. There are a number of attractive sections but as with many Russian works the maps loave much to the imagination. The work is interspersed with innumerable fold-out correlation charts from which are seen, at a glance, both the regional variations and the contemporary Soviet view of stratigraphic classification.

\section{W. B. Harland}

\section{Genetics practical}

Practical Genetics. Edited by P. M. Sheppard. Pp. xii +337. (Blackwell Scientific: Oxford and London, 1973.) $£ 8.50$.

FIRST experiences of practical classes in biology are usually traumatic but rewarding for students and teachers alike, for what they observe for themselves often differs from what they were led to expect by plausible lecturers and the pedantry of textbook figures. This is particularly so in genetics practicals where the main technique of crossing and progeny analysis rarely provides the same goodness of fit to expectation which blessed Mendel's results. A working knowledge of statistics goes hand in hand with practical work in genetics and this, coupled with problems of obtaining suitable material, has given rise to the misleading impression that successful practicals are too difficult to organise.

Anyone concerned with teaching genetics at levels between lower sixth 